\title{
Seen but Not Heard: A Case Study of K-12 Web Archiving and the Importance of Student Participation in the Archives
}

\section{By JoyEllen Freeman}

\begin{abstract}
"Little boys should not loll on chairs." "Little girls should be seen and not heard. ..." Have we not almost all learnt these expressions of old foozles: and uttered them ourselves when in the square-toed state? ${ }^{1}$
\end{abstract}

-William Makepeace Thackeray

\begin{abstract}
Prior to the 1990s, student interaction with archives was limited. K-12 educators often struggled to access archival materials and primary sources, especially because most archivists failed to include $\mathrm{K}-12$ audiences in outreach and programming efforts. Digitization and the emergence of the Internet during the late twentieth century changed the relationship between $\mathrm{K}-12$ students and archives. Educators and students now have access to millions of digital archives online, and most statewide education standards require students to engage with primary sources regularly. As a result, the archival literature devotes more time and space to discussing the relationship between K-12 students and archives. This article uses the Archive-It K-12 Web Archiving Program, which began as a partnership between the Library of Congress and the Internet Archive's Archive-It service, as a case study in participatory archiving. The research relies on interviews with educators involved in the program, published reviews of the program, and a survey of archival and pedagogical scholarly literature. The article concludes that participatory archiving has academic and sociocultural benefits for $\mathrm{K}-12$ students. Participating in archival processes increases students' digital literacy and critical thinking skills, transforms their understanding of history and personal identity, and gives them a means of expressing their culture. The research is significant because it shows that K-12 students have a voice in the historical record, and it challenges archivists to develop more opportunities to allow these voices to be heard.
\end{abstract}

\section{Introduction}

Prior to the late twentieth century, students in North America had few interactions with archives because many archivists believed students are too young to engage with archival materials and educators did not understand how to gain access to primary sources and integrate them into classroom curricula. ${ }^{2}$ When students did experience archives, it occurred mainly as a special activity involving preselected analog materials. These experiences relied on heavy mediation from archivists and educators yet required little effort from students. ${ }^{3}$ In the 1990s, a large-scale shift took place. The rapid increase of technological opportunities coupled with changing teaching methods in the $\mathrm{K}-12$ sector 
made in-depth student engagement with primary sources a greater priority in classroom instruction. As a reaction to this trend, archivists have become more interested in the needs of K-12 students over the past 25 years. Now, more archival literature focuses on K-12 archival needs, and more archival programs have emerged to help educators gain better access to primary sources and use them in ways that foster students' critical thinking.

Since the dawn of the twenty-first century, another shift has taken place. Archivists have come to acknowledge that communities, particularly underrepresented communities, not only desire to interact with archives but also to participate in the archival process. Although archivists have widely discussed and promoted student engagement with archives since the 1990s, the archival literature has ignored the underrepresentation of K-12 student voices within the archival record itself. Research studies that have explored how and why K-12 students create records and information do not fully address why students generally have been denied opportunities to decide which records are worthy of long-term preservation. ${ }^{4}$ This "seen but not heard " tradition, however, is changing. This article explores the recent paradigm shift now encouraging students to engage in archival processes on a deeper, more participatory level. To demonstrate this shift in tradition and its implications, this article uses the Archive-It K-12 Web Archiving Program of the Internet Archive as a case study of how participatory archiving, particularly web archiving, can empower student communities. The case study is based on reviews of program statements published by Archive-It and the Library of Congress as well as e-mail and Skype interviews with educators from various parts of the United States.

The article concludes that participating in archival processes and having a voice in the digital record of humanity empowers students. Participatory archiving benefits students academically because it develops critical thinking and technical skills that complement current state-level education standards. Participatory archiving also has sociocultural benefits for students because it transforms their understanding of history and heightens the significance of their own existence; it gives them a space to express their culture; and it helps them garner and articulate a sense of personal identity within the vast $\mathrm{K}-12$ student community.

\section{The K-12 Community and a Changing Relationship with the Archives}

Although the $\mathrm{K}-12$ community at large is comprised of individual $\mathrm{K}-12$ units that vary socially, culturally, politically, and economically around the country, this community shares a common history when it comes to interactions with archives. Prior to the 1990s, inconsistency and, at times, neglect mostly characterized this history. For years, archivists did not consider the $\mathrm{K}-12$ student community to be a user group requiring much attention. According to Anne Gilliland, children were "often excluded from archival programming because they [were] perceived as lacking the cognitive and educational tools to comprehend or work effectively with primary sources or finding 
aids." ${ }^{5}$ Although some early initiatives, such as National History Day, and organizations encouraged students to engage with primary sources, many of these initiatives existed outside the parameters of traditional classroom activities. ${ }^{6}$ For the majority of students, archival exposure in a classroom setting was limited to a showcase of preselected analog records or artifacts, often "through the development of exhibits, educational packets, or tours," as opposed to hands-on interaction with records. ${ }^{7}$

In the latter part of the twentieth century and into the beginning of the twenty-first, the archival needs of the $\mathrm{K}-12$ student community began to receive attention in the professional literature. Inspired by opportunities made possible through new technological advances like the World Wide Web and collections of digital primary sources, scholars like Roxanne Medrinos and Anne Gilliland were among the first to explore the integration of digital archives in K-12 classrooms. By the new millennium, scholarly articles about the use of archives in K-12 settings had increased in archival literature, yet these writings were still sporadic. Pedagogical literature, on the other hand, reflected this trend at a much faster pace. According to Julia Hendry, a search of the ERIC education database in 2006 retrieved 452 articles published between 2000 and 2005 with the descriptor "primary sources." 8

Multiple factors have contributed to educators' heightened interest in archival materials since the late twentieth century. These include changes in teaching methods, highstakes testing, and the emergence of Common Core standards. Since the last decade of the twentieth century, increased digitization and greater accessibility to primary source documents via the Internet have provided a new wealth of opportunities for teachers. As early as 2002, education scholars such as John K. Lee took notice of the millions of historical documents placed online in the span of just one decade. ${ }^{9}$ Lee noted that while some teachers managed to use limited archival holdings in their classrooms prior to the Internet, "the Web has made primary source documents available to students at all levels in almost all places." ${ }^{10}$ Michael Eamon concurs that "the Internet has revolutionized the way we can access archival material. . . . Students do not have to view documents as mere illustrations of historical events; they can now gain a richer historical perspective."11 Eamon's point speaks to one of the main goals educators hope to achieve by incorporating primary sources into $\mathrm{K}-12$ classrooms: inquiry-based learning.

Web-based digital resources have become a staple in K-12 classrooms largely due to shifts in teaching methods toward inquiry-based learning. This method is "an approach to teaching that emphasizes the process of discovery on the part of the student, rather than the straightforward transmission of knowledge from teacher to student." ${ }^{12}$ Also known as learning by doing, inquiry-based learning "empower[s] students to construct a more personal understanding of history." ${ }^{13}$ The academic importance of inquirybased learning has risen since the early 2000s. Many high-stakes tests such as the New York State Regents Exam and the College Board's Advanced Placement (AP) History Exam contain document-based questions (DBQs) that require students to examine and analyze primary source documents. ${ }^{14}$ Even more recently, the adoption of the 2010 Common Core State Standards Initiative in 43 states, the District of Columbia, and 
almost all other US territories has re-emphasized the importance of primary sources in the classroom. Under the Common Core standards, middle and high school students must analyze primary and secondary source documents as an integral part of the social studies curriculum. ${ }^{15}$ Likewise, Common Core standards require students in all grades to master reading skills for informational texts. Using primary sources satisfies this requirement because it helps students comprehend, critique, and integrate information from various sources. ${ }^{16}$ These educational changes in the last two decades have opened the door for teachers to seek help from archivists.

Educators and archivists around the country have developed large- and small-scale partnerships to integrate primary source materials into K-12 classrooms. One such partnership began more than three years ago when a first-grade teacher in northwest Ohio expressed interest in bringing her students to visit the Bluffton University Archives in Bluffton, Ohio. Now every year, Carrie Phillips - the archives and special collections librarian at Bluffton - packs a vintage suitcase with seven items from the archives and leads young visiting students in a discussion about the items and how each one contributes to an understanding of the past. ${ }^{17}$ Not only do the students and teachers react positively to the program, but Phillips is even "surprised at how engaged and excited the students [are]." ${ }^{18}$ Likewise, archivists at Virginia Tech received an unexpected request from a teacher seeking archival assistance for her students participating in National History Day. What began as a relatively "impromptu" partnership between a few archivists and one teacher led to the Virginia Tech Special Collections hosting 50 middle school students and showcasing items from the Civil War to complement the students' current history unit. ${ }^{19}$ The experiences of these university archivists show that even the smallest and most unexpected partnerships between archivists and educators can create meaningful experiences for students.

A larger example of a partnership between archivists and educators is the National Archives and Records Administration's DocsTeach site, which began in 2010. ${ }^{20}$ This site provides educators with digital primary sources to use in history classes along with ready-made tools and interactive features for building new activities. One of the largest and longest-running partnerships between archivists and educators takes place at the Library of Congress. The American Memory Project, begun in 1990, was an early effort to digitize historical collections as "resource[s] for education and lifelong learning." ${ }^{11}$ Since then, the Library of Congress has led the way in making digitized archival content available to teachers and applicable to a wide range of school curricula. In addition, the Library of Congress provides summer institutes to educate teachers about using primary sources, facilitates discussions among educators through the Teaching with the Library of Congress blog, and publishes primary source sets and lesson plans that make digital history both accessible via the web and applicable to the classroom. Kelly Hillesland, a high school teacher in California, blogged in 2014 about her experience using primary sources from the Library of Congress's digital collections to teach students about the March on Washington. Hillesland wrote, "[I was] amazed by the voracity with which the students approached the work." ${ }^{22}$ She also noted that through 
this experience, "the students did the work of historians, which is a major goal we have for our students, especially in the age of Common Core standards." ${ }^{23}$

Incorporating archival materials into $\mathrm{K}-12$ classrooms has been challenging. Before the advent of digital history resources, teachers' access to primary source materials was extremely limited. ${ }^{24}$ Now that countless digital archives are available through the web, the problem is knowing how to properly incorporate such voluminous digital collections into classroom curricula. While many teachers see and appreciate the value of primary sources in the classroom, others consider this a difficult and frustrating process, particularly if they are not familiar with archival materials themselves. ${ }^{25}$ According to Ruffin and Cappell, archival methods of arrangement and description may be unfamiliar to educators because "unlike books in a library catalog, archival documents are not cataloged at the item level. Instead collections of documents are broadly described. ... [Teachers] may not even think to consider these types of resources, or they may be intimidated by them." ${ }^{26}$ Despite these challenges, many educators and scholars agree that incorporating archival materials into classrooms creates a more positive learning environment and renders a higher level of student engagement in course material. As Michael Eamon stated, "using primary sources ... transcends the rote learning of facts and figures. It encourages critical thinking skills, introducing students to . . the nature of collective memory and to other like aspects in the construction of history." 27

Student interaction with archives can be classified into distinct "levels" in terms of purpose and intensity. The most basic level of archival engagement is often targeted at younger $\mathrm{K}-12$ students. It occurs in a controlled environment where an archivist or a teacher pulls selected materials from the archives and leads a show-and-tell experience. Traveling trunks, traveling exhibits, and other preselected assemblies of materials are examples of these kinds of programs, where the goal is to let students experience "cool stuff" within the archives without requiring any substantial analysis of the materials. The next level of archival engagement involves identification, examination, and analysis of materials by older K-12 students. Activities may include observing, analyzing, and interpreting primary sources; using archives to gain historical and literary context; and learning to locate primary sources in both digital and analog environments. The purpose of archival engagement on this level is not to focus on the novelty of materials but rather to enhance students' critical thinking and research skills. It represents a higher, more intense level of engagement because students can "construct meaning from primary materials and critically examine those meanings"; hence, "they feel more invested in the results." ${ }^{28}$

These first two levels of archival engagement have predominated in the student community since the late twentieth century. Eleanor Dickinson and Matthew Gorzalski stated, "Traditional archival outreach methods for K-12 students teach children how to be historians-not archivists," as these methods generally focus on teaching document analysis rather than archival processes. ${ }^{29}$ But this landscape is now changing. In a world where digitization and Web 2.0 now foster participatory archives on a much larger scale than before, the archival community is experiencing what Terry Cook described as a 
shift in the "archival paradigm." ${ }^{30}$ According to Cook, the archival landscape has now moved toward "a community of archivists" where "citizens have a new agency and a new voice" in the construction of societal memory and identity. ${ }^{31}$ This change in archival thought has also changed the relationship between $\mathrm{K}-12$ students and archives by introducing another level of interaction. The third level of student interaction with archives values students as participants in the archival process. It gives them a chance to influence the historical record, which, for many years, they simply had to accept.

\section{An Emerging Culture of Participation in the Archives}

Ideas about participatory archives and increasing levels of user engagement became more prevalent in archival conversations in the first decade of this century. Since then, various definitions of the concept of participatory archives in the digital era have surfaced. One of the founding definitions originated with Isto Huvila, who described three main features of participatory archives: "decentralized curation, radical user orientation, and contextualization of both records and the entire archival process." ${ }^{32}$ In other words, a functioning, participatory archives not only requires an emphasis on the usability and context of archival resources but also on the sharing of responsibilities between the archivist and the archives' patrons. ${ }^{33}$ Elizabeth Yakel highlighted this aspect of sharing in her writings about participatory archives. In a presentation to the Society of American Archivists in 2011, she described the participatory archives as "a space where information is co-represented, credibility norms co-established, knowledge co-created, authority co-negotiated, and control is shared." ${ }^{34}$ Just as "Web 2.0 is about connection, collaboration, [and] community," Yakel asserted that participatory archiving "connects communities with collections ... history and identity." ${ }^{35}$

This article relies primarily on Kate Theimer's definition of participatory archives: "An organization, site, or collection in which people other than the archives professionals contribute knowledge or resources resulting in increased understanding about archival materials, usually in an online environment." ${ }^{36}$ Theimer's writings about participatory archives often address questions of practicality and utility - how a participatory archives is created, used, and maintained. According to Theimer, "participation is different from engagement." ${ }^{37}$ The purpose of a participatory archives is not to solicit opinions, feelings, or recreational engagement with archives; it is to obtain useful contributions of knowledge and resources that can provide further insight into archival materials. ${ }^{38}$ Digital resources, particularly Web 2.0 technologies, allow patrons to participate in various ways, often through crowdsourcing, tagging, contributing archival materials, "remixing" archival content in new environments, preserving web content, or even creating new collections altogether. ${ }^{39}$ The gamut of ways a participatory archives can function poses questions about its definition and exposes ambiguities surrounding what constitutes a true "participatory" experience. Patricia Garcia said, "While the types of participation that archival projects request vary, the wide range of archival processes that participants complete are monolithically described as 'participation.'. . The nature and forms of archival participation need further analysis and articulation." ${ }^{40}$ 
Early participatory archives efforts employed a wide range of methods and produced a variety of results. One of the best known is the September 11 Digital Archive. Developed shortly after the 2001 attacks, the goal of this project is to preserve the history of the September 11 tragedy and its aftermath by collecting digital records that provide firsthand accounts of the event. Early on, the project brought about wide participation. Just two years after its establishment, the archive had collected over 100,000 personal narratives, e-mails, digital images, documents, and audio and video files. ${ }^{41}$ Other initiatives, however, struggled to attract the same level of user participation. One example is the Polar Bear Expedition Project, a collaborative effort between the University of Michigan's School of Information and the Bentley Historical Library. Unlike the September 11 Digital Archive, which asked users to contribute archival materials, the goal of the Polar Bear Expedition Project was to utilize social navigation features like bookmarks, comments, and link paths to facilitate more participatory archival experiences for users. The site opened for use in January 2006. The project studied user participation from January 2006 to June 2006 and found that users mostly ignored the social navigation features, possibly because they were unfamiliar with Web 2.0 technology at that time. ${ }^{42}$

In the last few years, many participatory archives have gained traction and attracted user participation. According to Dallas Hanbury, "Users have become increasingly confident using digital archives' participatory features." ${ }^{33}$ Initiatives such as the Occupy Wall Street Library, the United States Holocaust Memorial Museum's Remember Me? project, and the Library of Virginia's Civil War 150 Legacy project are just a few examples of participatory archives established since 2009. Similarly, institutions outside the United States, such as the National Library of New Zealand, display archival holdings in a Web 2.0 format, allowing patrons to comment, like, reblog, and retweet digitized images of archival materials. ${ }^{44}$ Just as Helen Willa Samuels called for strategic collaborations between records creators, administrators, archivists, and users 30 years ago, participatory archives also seek to create spaces where these same collaborations can take place. ${ }^{45} \mathrm{~A}$ participatory archives acknowledges that a multiplicity of voices strengthens archival collections by making them more accurate, complete, and genuinely representative of the past.

Many participatory archives revolve around the history of particular communities. The idea of participatory archives is especially attractive when communities feel that their presence in mainstream archives has been misrepresented. According to Michelle Caswell, community archives are essentially "independent grassroots efforts for communities to document their own commonalities and differences outside the boundaries of formal mainstream institutions. ${ }^{36}$ Community archiving is important because "many underrepresented communities mistrust the efforts of mainstream archives that have historically creat[ed] archives about rather than of the communities"; hence, participatory archiving represents a shift away from traditional archival authority and a movement toward shared authority. ${ }^{47}$ Since many underrepresented communities have taken it upon themselves to actively document their histories separate from archivists or other external voices rooted in the mainstream archives, the participatory archives concept provides a collaborative way for professional control and community control to converge in the hopes of making a better and more equally representative archives. 
Efforts to develop participatory archives often face stiff challenges. Getting enough participants can be difficult, particularly because many of these digital collections tend to "have devoted, but limited, followings." ${ }^{38}$ On the other hand, encouraging skeptical archivists to "loosen up control" 49 and engage in "radical trust" of the community and its participation abilities can be just as difficult. ${ }^{50}$ Nonetheless, participatory archiving fosters a unique partnership between archivists and patrons that benefits users, archivists, and the archives themselves. On a practical level, sharing archival responsibilities can contribute to a reduction in backlogs, help reduce the archivist's workload, and act as a means of promoting the archives. The social implications of participatory archives, however, are even more noteworthy. Because the concept of participatory archives represents "a community of archivists and users sharing the work of arranging, describing, and making information available," ${ }^{51}$ an increased level of transparency, trust, and diversity becomes embedded in the archives. According to Katie Shilton and Ramesh Srinivasan, community involvement in the archives not only helps "acknowledge and preserve [the] context" of records but also "allow $[\mathrm{s}]$ communities to preserve empowered narratives." ${ }^{2}$ Essentially, participatory archives acknowledge the voices of communities and individuals who traditionally remained outside of the archives.

\section{The Archive-It K-12 Web Archiving Program: A Case Study}

Web archiving is one way students can participate in the archival process. The International Internet Preservation Consortium (IIPC) defines web archiving as "the process of collecting portions of the World Wide Web, preserving the collections in an archival format, and then serving the archives for access and use. ${ }^{53}$ The earliest web archiving initiative began in 1996 when Brewster Kahle founded the Internet Archive ${ }^{54}$ - a nonprofit, publicly available, digital library. ${ }^{55}$ Since then, the value of web archiving has increased, as virtually every part of the globe depends more and more on web content for information exchange and social interaction. With many scholars now cognizant of the "Digital Dark Ages" 56 threat that could affect future generations' understanding of our recent past, recognition of the importance of saving web content has heightened. As Jackie Dooley stated, "Without periodic harvesting of the websites that host all of this information, the content is gone, gone, gone." ${ }^{57}$ Today, at least 64 web archiving initiatives exist worldwide. The Internet Archive remains the largest. ${ }^{58}$

Despite the growth of these programs that now preserve and make available petabytes upon petabytes of data, they still cannot capture everything. ${ }^{59}$ To help fill in the gaps and better serve organizations and communities looking for more control over the preservation of their web content, the Internet Archive began providing web archiving services to organizations beginning in $2004 .{ }^{60}$ One of its most popular services is ArchiveIt, established in 2006 on a subscription basis, to allow "users to create, manage, access and store collections of digital content." ${ }^{11}$ Archive-It is a web-based application that uses open source technology tools developed in-house at the Internet Archive and is maintained by a group of team members. ${ }^{62}$ Despite the opportunities Archive-It provided for many organizations and individuals, some voices were still missing. According to Cheryl 
Lederle, an educational resource specialist at the Library of Congress, one of these missing voices also constituted "one of the [web's] biggest user groups": K-12 students. ${ }^{63}$

A partnership between the Library of Congress and Archive-It team members established the K-12 Web Archiving Program in 2008. This program gives students an opportunity to participate actively in preserving and describing web content for future use. The program helps students identify and eventually preserve websites that are important to their lives and to their society while also challenging them to "build [an] awareness of the internet as a primary source and how quickly it can change." ${ }^{64}$ The pilot program for this initiative began in the spring of 2008, and the first academic school-year program began that fall. Managers of Educational Outreach and the Office of Strategic Initiatives at the Library of Congress along with members of Archive-It selected schools and educators to participate in the program. They based their selection on a pool of educators from the Library of Congress's teacher database, various e-mail listservs, respondents to advertisements posted on the Archive-It website, and word of mouth referrals. ${ }^{65}$ Teachers received online training that both introduced them to Archive-It and taught them how to use Archive-It's services in a classroom setting. ${ }^{66}$ Training included one-on-one webinars, PowerPoint presentations, videos, the $\mathrm{K}-12$ resources portal, and other specialized resources to familiarize educators with the concept of web archiving and teach them how to make the Archive-It program a reality in the classroom. The successful implementation of the program at three high schools during the spring of 2008 and nine high schools during the 2008-2009 academic school year convinced Library of Congress and Archive-It staff members that students should be involved making decisions for web heritage preservation. ${ }^{67}$

This analysis of the K-12 Web Archiving Program is based on interviews conducted during the summer of 2015 with four educators involved in the program. They were chosen because of their extensive experience with the program, as all four joined the initiative during its first two years, and three out of the four are still regularly involved with the program. All four educators can attest to the program's original goals as well as the subsequent changes, challenges, successes, and evolution of the program over the past seven years. The educators also bring a wide range of perspectives, as they hail from a variety of institutions located in New England, the mid-Atlantic states, and the Southeast.

Since its inception, the K-12 Web Archiving Program has emphasized the importance of student-generated collections. According to Neme Alperstein, a New York City public school teacher who has been web archiving with students since 2008, the web archiving program asks students "what they want to archive, not their parents. Students [feel] this is their project." ${ }^{68}$ Although they conduct web archiving efforts with the guidance of teachers, students are in charge of selecting, capturing, describing, and reviewing collections. Patricia Carlton, a media specialist at Mount Dora High School in Mount Dora, Florida, has been involved in the K-12 Web Archiving Program for nearly eight years, and in that time she has learned how to give students just enough autonomy. She says her students "generally have to write what their collection is going to be and 
why it's significant to them . . . then they surf the web." ${ }^{\prime 9}$ After students decide on a collection topic and choose the initial sites, better known as "seeds," that best document their topics, they use Archive-It's open source technology to crawl and capture sites based on criteria the students set beforehand, including crawl frequency, crawl depth, and other parameters for the scope of the crawl. Students also are responsible for creating metadata for their collections. This step is important for students; Cheryl Lederle believes that "creating metadata is very useful" 70 for developing English and writing skills. This is consistent with the state-led Common Core standards, which require students in kindergarten all the way through 12 th grade to publish writing using digital tools. ${ }^{71}$ Writing metadata is also important for students' understanding of archives. Patricia Carlton tells her students that "their description is part of the record, part of the archive ... [because] it gives context."72 By selecting, preserving, and describing their own collections, students become what the Library of Congress has affectionately deemed "America's young archivists." 73

Through the K-12 Web Archiving Program, Archive-It has developed partnerships with approximately 30 schools around the United States. Some of these schools have remained partners in the program for nearly eight years. Through these partnerships, K-12 students are responsible for the creation of over 200 web archive collections and have preserved over 4,000 URLs. ${ }^{74}$ Although every school, every student, and every collection is different, the students within the $\mathrm{K}-12$ community are creating what is essentially a massive community archives. According to Andrew Flinn, Mary Stevens, and Elizabeth Shepherd, "The defining characteristic of community archives is the active participation of a community in documenting and making accessible the history of their particular group and/or locality on their own terms." 75 As students add their individual voices and perspectives to this multi-institutional, multigeographical, and diverse community archives, they learn to conceptualize and express their own identities in ways most of them have never experienced before.

\section{Meeting the Challenges of K-12 Web Archiving}

Dozens of schools have participated in Archive-It's K-12 Web Archiving program through history courses, English courses, special library programs, and even afterschool clubs. On a national scale, however, web archiving is still unknown in most primary and secondary school classrooms. Connecting the Web Archiving Program to curricular needs was one of the biggest challenges the program initially faced. According to Cheryl Lederle, "A lot of curriculum programs are tightly prescribed, so teachers don't always have the latitude to fit [web archiving] into the program." ${ }^{76}$ Because educators are expected to operate autonomously after they receive the initial Archive-It training, the web archiving program does not come with explicit and clear-cut connections to state standards that school administrators look for, which often exacerbates the curriculum integration challenge and makes it more difficult for educators to know how to best take advantage of the program academically. ${ }^{77}$ Patricia Carlton found that it is sometimes a struggle to implement the program into classroom curricula in a way that teachers and department heads will support. ${ }^{78}$ Carlton admitted that while she initially 
wanted to introduce web archiving to Advanced Placement (AP) history students at her school, they simply "had too much material to cover" and did not have space in the curriculum for web archiving. ${ }^{79}$

Some teachers have addressed these challenges in out-of-the-box ways. Paul Bogush, a social studies teacher at James H. Moran Middle School in Wallingford, Connecticut, began an afterschool program for web archiving, as this was the best way he could implement the program in his school without disrupting the standard curriculum. ${ }^{80}$ According to Bogush, the web archiving program "is an academic thing," so it can be unappealing to students in an afterschool setting. ${ }^{81}$ After a full day of classes, "it's hard to ask [the students] to come back and do something academic," he said. ${ }^{82}$ Nonetheless, each year students agree to be involved. Bogush is known for requiring his students to use technology as a part of regular class work, including blogs, wikis, and podcasts, so the web archiving program became a perfect complement to his already technologybased classroom. ${ }^{83}$ Although he has had success with the afterschool program, Bogush's true desire is to incorporate web archiving into his classroom curriculum, as he believes the program "fits very neatly into a history class." ${ }^{4}$

Neme Alperstein, on the other hand, has incorporated web archiving into her classroom for years. According to Alperstein, who teaches gifted fifth grade students at PS 174 William Sidney Mount in Queens, New York, "It is actually easy to justify [web archiving] in any classroom according to state curriculum as long as the teacher is not held to a 'script.' I am fortunate in that the leadership in my school understands the power and importance of web archiving." ${ }^{85}$ Alperstein also noted that web archiving complements Common Core standards that require the development of student "research skills, analysis skills, reading informational text, collaborative skills, and more." 86 The Common Core website confirms Alperstein's statement, as there are more than 20 standards across all grade levels that require student engagement with "digital texts," "multimedia presentations," "technology," and the "Internet." ${ }^{87}$ Patricia Carlton collaborated with an English teacher at her school and successfully created a rubric for the web archiving program that aligns with Common Core literacy standards. ${ }^{88}$ So, although the academic value of the $\mathrm{K}-12 \mathrm{Web}$ Archiving Program is evident and the corresponding state standards exist, integrating these two factors remains a work in progress. As Alperstein's example suggests, the ease with which teachers can integrate web archiving into their classrooms largely depends on the support of their schools and the overall flexibility of a school's curriculum. Teachers may feel that they lack the necessary resources and/ or administrative support to make web archiving an integral aspect of learning. When asked if she would like to see more curriculum materials to help integrate web archiving into school classrooms, Patricia Carlton responded, "That would help. I've pretty much learned as I've gone along [but] I would love to have another way of teaching about the history of the web [and] the structure of the web." ${ }^{89}$

A further challenge to implementation is the absence of clear standards of evaluation. To fully incorporate the web archiving program academically, educators must, to some extent, evaluate students based on the achievement of stated goals. In this case, the 
main goal is the successful completion of a web archive collection. But just as educators lack guidance to help integrate the program academically, evaluation standards are sorely lacking as well. Currently, no standard ways exist for educators to measure what constitutes a satisfactory web archive collection and how the completion of such a collection translates into a grade. These discrepancies are not only prevalent among schools but within them as well. Patricia Carlton noted,

Until last year, most of the teachers with whom I worked did not give grades for student participation, but awarded participation points that would be used to average into a daily grade or boost someone's border line grade. But, there were two teachers who really graded their students' efforts. . . . The social studies teacher ... graded the web archiving project as a contemporary history research project. ... The English teacher was initially more interested in [students'] analysis of web content. . . . But once testing began, the grading of their web archiving project ended. ${ }^{90}$

While it is positive that the web archiving program is flexible enough to fit into a variety of K-12 subjects and areas of study, at this point, it seems that the academic adaptability of the program is uncertain and varies too dramatically among schools and between educators to become a long-term part of classroom curricula. Hence, it may be more helpful for educators to rely on the sociocultural implications of the program to measure student learning and growth.

\section{K-12 Web Archiving: What Students Learn}

Web archiving programs are process oriented and give students a chance to make meaning out of the experience on their own. Hence, when it comes to student development and growth, the actual process of web archiving may be just as important as the collections created from it. Since the onset of the K-12 Web Archiving Program, its social and cultural benefits have been a major draw. One of the program's initial advertisements from July 2008 promoted its ability to "stimulat[e] students to think about history in the context of their own lives." ${ }^{91}$ More recent descriptions highlight the program's ability to give students "a new perspective on saving history and culture, allowing students to actively participate and make decisions about what content will be saved." 92 While it is beneficial to evaluate students based on academic standards to ensure they are grasping the necessary skill sets and prescribed learning objectives, web archiving gives students a rare opportunity to frame themselves socially and individually. Neme Alperstein's treatment of the program supports this notion:

I try to shy away from the grading situation as I want this to be innovative and the students should feel that there is no penalty in taking risks. The fact that they complete the archiving, enter metadata, research sites within a category, and work collaboratively earns them a level of prestige in the class and demonstrates mastery of the tasks at hand. ${ }^{93}$ 
In addition, the process of web archiving can bring meaning to learning because it points students inward and asks them to evaluate what is important to themselves and their world. Paul Bogush sees this process as significant to his students' self-esteem and personal pride. He believes that in traditional education, "We mostly give kids 'fake assignments.' These assignments will be given a grade and thrown in the trash." His students appreciate web archiving because "for the first time, they are being asked to be a part of something that is permanent," something that requires them to "write their own history." 94 This inward focus is both unique and important because it empowers students to redefine their understanding of history, cultural expression, and personal identity.

Web archiving gives students a new perspective on history because it gives them a place in history. Even though traditional methods of student engagement with archives benefited students by bringing excitement to history and introducing them to "the elements that helped construct the vision of the past," ${ }^{95}$ the students themselves were left out of this historical construction. By allowing students to select, capture, describe, and preserve websites that are important to their lives, students are now participating in the creation of history instead of just viewing it or analyzing it. According to Paul Bogush, web archiving shows his students that "each one of them brings a bias to what is going to be picked. Now they realize that with every source they use there's a bias with that source. . . I It's no longer they can just take a primary source and take it at face value."96 In this way, web archiving brings a new understanding to history that other forms of $\mathrm{K}-12$ archival engagement cannot. The idea of influencing history often overwhelms students at first. When Bogush's students first began archiving, they would constantly ask him, "Should I save this website?" to which he replied, "I can't decide . . . if it's a website that represents a little part of you, then that is what you would save." ${ }^{\prime \prime}$ One student from James H. Moran Middle School demonstrated his newfound understanding of history when he stated, "When you archive a website, it's being preserved forever ... you're like writing history . . you're like writing a history textbook." ${ }^{98}$ Likewise, Patricia Carlton noted that when her students are web archiving "they feel important" because they enjoy being a part of an initiative that is larger than themselves. ${ }^{99}$ Hence, web archiving not only heightens students' understanding of history, but it also heightens the significance of their own existence.

Web archiving allows students to document culture. Jeanette Bastian affirmed the importance of cultural documentation in the archives when she stated, "Without deep knowledge of its core cultural events, it might be difficult, even impossible, to truly document any community." ${ }^{100}$ According to Bastian, expressing culture in an archives does not mean limiting these expressions to traditionally accepted forms of records, but rather, it involves creating an inclusive space where "traces and signifiers of cultures and traditions fit within an archival structure." ${ }^{101}$ As Christopher Lee stated, "Human activity leaves traces. ... [And] many of the traces of individuals are now being created and distributed through the web." ${ }^{102}$ Similarly, when students select websites for preservation, they are documenting traces of their cultural activities. Over the years, participants in the K-12 Web Archiving Program have created a wide variety of collections that document global, national, and local adolescent culture, including A Day in the Life, 
Only 90s Kids Remember, 2010 Lifestyle/Fads, Food Food Food, Life in 2011, and Our Community. ${ }^{103}$ Even though the websites captured in these collections will never become or replace the acts of driving to school, picking out fashionable clothes, enjoying a high school football game with friends, or making weekly trips to a local restaurant, captures of these sites represent those cultural performances. Allowing students to document their culture through a subject-centered web capture is more than a lesson in digital literacy. It facilitates what Bastian called "cultural justice," where students feel confident that their expressions of culture matter to the world they live in and are worthy of preservation. ${ }^{104}$

As K-12 students express culture through web archiving, they also shape and articulate their own personal identities within the larger K-12 community. Many scholars, including Joan Schwartz, Terry Cook, and Rodney Carter, have suggested that archives themselves have the power to shape and influence an understanding of personal identity. According to Schwartz and Cook, "Archives—as records—wield power over . . . how we know ourselves as individuals, groups, and societies." ${ }^{105}$ Likewise, Carter asserted that individuals or groups lacking sufficient archives may struggle to form an identity. ${ }^{106}$ However, for K-12 students, the archival process may influence identity formation more than the archives themselves. In her essay "Evidence of Me," Sue McKemmish referenced Anthony Giddens, who said personal identity is found "in the capacity to keep a particular narrative going." ${ }^{107}$ McKemmish contended that "record keeping can be one way of 'keeping a particular narrative going"' because "it is a way of evidencing and memoralising our lives - our existence, our activities and experiences, our relationships with others, our identity, our 'place' in the world." ${ }^{108}$ Similarly, the process of web archiving helps keep the personal narratives of K-12 students going. It helps them understand, shape, and articulate the areas of their lives that converge to create their multifaceted identities. The students belong to the all-encompassing concept of the $\mathrm{K}-12$ community, yet, as individuals, they carry distinct social, geographical, ethnic, economic, and experiential factors that affect how they determine what is important to preserve and what is not. To make these appraisal decisions for web archive collections, students must think about and, sometimes, rediscover how they identify themselves in society. One student from James H. Moran Middle School described this phenomenon in reference to her school's web archiving experience in 2010: "If you look at it collectively, then yes, [the web archive collection] does represent teenagers in 2010, but if you look at . . . say sites that just I archive, then that's just me; it's not the entire generation of teenagers." 109

Another student from the same school noted that many students' web archive collections share sites in common such as Facebook.com and MTV.com, because these sites are of interest to most teens. At the same time, students represented aspects of their individual identities in the web archive collections by selecting sites that reflect aspects of their personal lives such as dance, soccer, gaming, film animation, music, and anime. ${ }^{110}$ These observations show how the process of selecting, capturing, preserving, and describing websites can give students a greater understanding of their own identity and the identities of their peers. Through the creation of web archive collections, students 
can articulate these identities and decide for themselves where they belong within the K-12 community and within society at large.

\section{Conclusion}

In 2004, Barbara Craig said, "We choose to keep documents largely to make sense of our place in the world. . . Keeping and destroying ties us to records of our life and shows new generations what we valued enough to record and keep." 111 The K-12 Web Archiving program demonstrates Craig's assertion. Without a doubt, students' web archive collections have utilitarian benefits. For educators, these collections provide tangible evidence of students' digital literacy skills. For future researchers, the web pages preserved in these collections will be of great use when studying twenty-first-century society and culture. It is necessary, however, to consider the powerful effects that the web archiving process can have on students in the present. Web archiving provides a unique opportunity for student voices to contribute to the historical record. By web archiving, students become participants in "the process of memory-making and identity formation," which, in past years, was generally left to archivists and historians. ${ }^{112}$ For such young students, this participation can be most empowering. As Paul Bogush stated, "This may not be up there with preserving the Declaration of Independence, but to those students that are involved in the project, it is just as important." ${ }^{113}$

In this article, the Archive-It K-12 Web Archiving Program served as a test case for examining the implications of student participatory archiving. For K-12 students, engaging in participatory archiving initiatives like the K-12 Web Archiving Program can be a means of empowerment. Students are empowered by the collections they create but also by the journey they must take to create them. By selecting, preserving, and describing the digital content that has come to define their Internet-based world, students have a chance to contribute their voices to future research and scholarship. As students share in the responsibility of deciding "what the future will know about its past," 114 they expand their perspectives on the intersecting forces of history, community, culture, and personal identity while also gaining technical and critical thinking skills.

While this article provides a foundation for understanding the implications of $\mathrm{K}-12$ web archiving and archival participation, it is limited by the relatively small number of interviewees. Further research should include more extensive questioning of a wider variety of educators across the country, perhaps using survey techniques in addition to interviews. Further research should also use metrics to investigate the effects of web archiving on student learning and development. Quantitative data representing the academic and social impact of web archiving would be of great use to educators and archivists as they develop future web archiving initiatives. In addition, this article solely explores the implications of web archiving within the $\mathrm{K}-12$ sector, but further research is still needed to assess the benefits, challenges, and implications of web archiving initiatives for other student communities. This study joins a growing collection of archival literature calling on us to abandon the "too young," "too difficult," and "seen but not 
heard" mentalities that restricted students to minimal experiences with archives in past decades. Students are and will continue to be part of the archives.

\section{ABOUT THE AUTHOR}

JoyEllen Freeman is the outreach/special collections archivist at Kennesaw State University. She holds a master's degree in archival studies from Clayton State University and a bachelor's degree in English from the University of Georgia. Freeman is a 2015-2017 Association of Research Libraries/Society of American Archivists Mosaic Fellow and currently serves as the assistant outreach manager for the Society of Georgia Archivists. Her professional interests include the use of archives in K-12 and undergraduate education, community archives and outreach, rare books, and archives in fiction. Freeman served as an intern for Archive-It during the summer of 2015.

\section{NOTES}

1. William Makepeace Thackeray, "On a Chalk-Mark on the Door," in Roundabout Papers (circa 1860), Project Gutenberg, 2006, accessed July 15, 2015, www.gutenberg.org/files/2608/2608-h/2608-h .htm\#link2H_4_0012.

2. Ellen Ruffin and Laura Cappell, "Dispelling the Myths: Using Primary Sources in the K-12 Classroom," The Journal of the Association for Library Service to Children 7, no. 1 (2009): 26.

3. Anne J. Gilliland-Swetland, Yasmin B. Kafai, and William E. Landis, "Integrating Primary Sources into the K-12 Classroom," Archivaria 48 (1999): 89, accessed June 1, 2015, journals.sfu .ca/archivar/index.php/archivaria/article/view/12718/13896.

4. See Ciaran B. Trace, "Resistance and the Underlife: Informal Written Literacies and Their Relationship to Human Behavior," Journal of American Society for Information Science and Technology 59, no. 10 (2008): 1540-54.

5. Anne J. Gilliland-Swetland, "An Exploration of K-12 User Needs for Digital Primary Source Materials," The American Archivist 61, no. 1 (1998): 137, accessed June 26, 2015, americanarchivist .org/doi/pdf/10.17723/aarc.61.1.w851770151576103.

6. For more information about National History Day, visit National History Day, www.nhd.org.

7. Gilliland-Swetland et al., "Integrating Primary Sources into the K-12 Classroom," 89-90.

8. Julia Hendry, "Primary Sources in K-12 Education: Opportunities for Archives," The American Archivist 70, no. 1 (2007): 116, accessed June 24, 2015, americanarchivist.org/doi/pdf/10.17723/ aarc.70.1.v674024627315777.

9. John K. Lee, "Digital History in the History/Social Studies Classroom," The History Teacher 35, no. 4 (2002): 504.

10. Ibid.

11. Michael Eamon, "A 'Genuine Relationship with the Actual': New Perspectives on Primary Sources, History, and Internet in the Classroom," The History Teacher 39, no. 3 (2006): 304-5.

12. Hendry, "Primary Sources in K-12 Education," 117.

13. Lee, "Digital History," 504.

14. Hendry, "Primary Sources in K-12 Education," 121-22. 
15. "English Language Arts Standards: History/Social Studies: Grades 6-8, Common Core State Standards Initiative," 2015, accessed June 15, 2015, www.corestandards.org/ELA-Literacy/ RH/6-8; English Language Arts Standards: History/Social Studies: Grades 9-10, Common Core State Standards Initiative, 2015, accessed June 15, 2015, www.corestandards.org/ELA-Literacy/ RH/9-10; English Language Arts Standards: History/Social Studies: Grades 11-12, Common Core State Standards Initiative, 2015, accessed June 15, 2015, www.corestandards.org/ELA-Literacy/ RH/11-12.

16. Denise N. Morgan and Timothy V. Rasinksi, "The Power and Potential of Primary Sources," Reading Teacher 65, no. 8 (2012): 586.

17. Carrie Phillips, "When First Graders Visit the Archives," Archival Outlook (March/April 2015): $3,24$.

18. Ibid., 24.

19. Marc Brodsky, Kira Dietz, and Carolyn Meier, "Did You Fight in the Civil War?: Introducing Special Collections to K-12 Students," Archival Outlook (July/August 2011): 10-11.

20. Stephanie Greenhut and Suzanne Isaacs, "The Archives Offers Teachers New Tools to Stir Student Interest in History," Prologue Magazine, Fall 2010, accessed June 25, 2015, www.archives.gov/ publications/prologue/2010/fall/docsteach.html.

21. “About American Memory," Library of Congress, accessed June 24, 2015, memory.loc.gov/ammem/ about/index.html.

22. Kelly Hillesland, "Integrating Writing and U.S. History: Primary Sources and the Library of Congress," Teaching with the Library of Congress (blog), February 11, 2014, accessed July 1, 2015, blogs.loc.gov/teachers/2014/02/integrating-writing-and-u-s-history-primary-sources-and-thelibrary-of-congress-summer-teacher-institute/\#comments.

23. Ibid.

24. Lee, "Digital History," 504.

25. Hendry, "Primary Sources in K-12 Education," 124.

26. Ruffin and Cappell, "Dispelling the Myths: Using Primary Sources in the K-12 Classroom," 27.

27. Eamon, "A 'Genuine Relationship with the Actual," 297.

28. Elizabeth A. Chase, “Teaching First-Year Writing with 'All the Detritus, Debris, and Ephemera' of Literary Manuscripts," in Past or Portal? Enhancing Undergraduate Learning through Special Collections and Archives, ed. Eleanor Mitchell, Peggy Seidan, and Suzy Taraba (Chicago: Association of College and Research Libraries, 2012), 105.

29. Eleanor Dickinson and Matthew Gorzalski, "More than Primary Sources: Teaching about the Archival Profession as a Method of K-12 Outreach," Archival Issues (2013): 7-8, accessed June 30, 2015, minds.wisconsin.edu/handle/1793/72393.

30. Terry Cook, "Evidence, Memory, Identity, and Community: Four Shifting Archival Paradigms," Archival Science 13, nos. 2-3 (2013): 95, accessed July 6, 2015, https://ezproxy.clayton.edu:2102/ docview/1355630005/CEB6933B876B4E14PQ/5?accountid=10139 (log-in required).

31. Ibid., 96-97, 117.

32. Isto Huvila, "Participatory Archive: Towards Decentralised Curation, Radical User Orientation, and Broader Contextualisation of Records Management," Archival Science 8, no. 1 (2008): 25.

33. Ibid.

34. Kate Theimer, "Participatory Archives: Something Old, Something New" (presentation, Midwest Archives Conference, Grand Rapids, MI, April 19, 2012).

35. Elizabeth Yakel, "Who Represents the Past? Archives, Records, and the Social Web," in Controlling the Past: Documenting Society and Its Institutions, ed. Terry Cook (Chicago: Society of American Archivists, 2011), 258.

36. Kate Theimer, "Exploring the Participatory Archives," ArchivesNext (blog), August 30, 2011, accessed July 15, 2015, www.archivesnext.com/?p=2319.

37. Theimer, "Participatory Archives: Something Old, Something New."

38. Ibid.

39. Ibid. 
40. Patricia Garcia, "Beyond Folksonomies: Assessing the 'Participatory Turn' in Archival Studies" (abstract from presentation, Archival Education and Research Institute, University of MarylandCollege Park, July 16, 2015).

41. Roy Rosenzweig Center for History and New Media and American Social History Project/Center for Media and Learning, The September 11 Digital Archive, "About," accessed July 11, 2015, 911digitalarchive.org/about; Ali Goldstein, "September 11 Digital Archive," The Literature of 9/11, University of Maryland, last modified 2014, accessed July 11, 2015, lit9-11.umd.edu/september11-digital-archive.

42. For further background information on the Polar Bear Expedition project, see Magia Ghetu Krause and Elizabeth Yakel, "Interaction in Virtual Archives: The Polar Bear Expedition Digital Collections Next Generation Finding Aid," The American Arcbivist 70, no. 2 (2007): 282-314. See also Dallas C. Hanbury, "Build It and Will They Come?: Participatory Digital Archives, Hesitant Users, and the Emerging Archival Commons," Provenance 32, no. 1 (2014): 49-62.

43. Hanbury, "Build It and Will They Come?," 59.

44. Chern Li Liew, "Participatory Cultural Heritage: A Tale of Two Institutions' Use of Social Media," D-Lib Magazine 20, nos. 3-4 (2014), accessed July 10, 2015, dlib.org/dlib/march14/liew/03liew .html.

45. Helen Willa Samuels, "Who Controls the Past?," in American Archival Studies: Readings in Theory and Practice, ed. Randall Jimerson (Chicago: Society of American Archivists, 2000), 200.

46. Michelle Caswell, "Seeing Yourself in History: Community Archives and the Fight against Symbolic Annihilation," The Public Historian 36, no. 4 (2014): 31, accessed July 30, 2015, ezproxy.clayton .edu:2076/stable/pdf/10.1525/tph.2014.36.4.26.pdf?acceptTC=true\&jpdConfirm=true (log-in required).

47. Katie Shilton and Ramesh Srinivasan, "Participatory Appraisal and Arrangement for Multicultural Archival Collections," Archivaria 63 (2007): 89, accessed July 10, 2015, journals.sfu.ca/archivar/ index.php/archivaria/article/view/13129/14371; Yakel, "Who Represents the Past?," 275.

48. Yakel, "Who Represents the Past?," 272.

49. Theimer, "Something Old, Something New."

50. Darlene Fitcher, "Web 2.0, Library 2.0 and Radical Trust: A First Take," Blog on the Side (blog), April 2, 2006, accessed June 10, 2015, library.usask.ca/ fichter/blog_on_the_side/2006/04/web-2 .html.

51. Hanbury, "Build It and Will They Come?," 57.

52. Shilton and Srinivasan, "Participatory Appraisal and Arrangement," 90, 95.

53. "Web Archiving," IIPC, accessed June 27, 2015, www.netpreserve.org/web-archiving/overview.

54. Brewster Kahle founded the Internet Archive with the goal of building an Internet library. The Internet Archive is now an expansive digital library containing millions of free and accessible books, movies, software, music, and more. The Internet Archive also hosts the Wayback Machine, which provides access to over 480 billion preserved web pages.

55. Daniel Gomes and Miguel Costa, "The Importance of Web Archiving for Humanities," International Journal of Humanities and Arts Computing 8, no. 1 (2014): 107; Lori Donovan and Scott Reed, "Archive-It Archiving and Preserving Web Content" (webinar presentation, June 2, 2015).

56. According to the Library and Information Science Wiki, "the Digital Dark Ages is a common term for a potential time in the future when a substantial portion of electronic forms of information has been lost." Library and Information Science Wiki, s.v. "Digital Dark Ages," last modified June 10, 2011, accessed June 3, 2015, liswiki.org/wiki/Digital_Dark_Ages. If this were to occur, many scholars believe that future researchers and historians would lack sufficient documentation of the twenty-first century and would be at a loss for understanding twenty-first-century history and culture.

57. Jackie Dooley, "Going, Going, Gone: The Imperative for Archiving the Web," hangingtogether.org (blog), OCLC, April 22, 2015, accessed June 1, 2015, hangingtogether.org/?p=5140.

58. Gomes and Costa, "The Importance of Web Archiving," 107; Donovan and Reed, "Archive-It Archiving and Preserving Web Content." 
59. Gomes and Costa, "The Importance of Web Archiving," 106.

60. Donovan and Reed, "Archive-It Archiving and Preserving Web Content."

61. Ibid.

62. Ibid.

63. Cheryl Lederle (educational resource specialist, Library of Congress), discussion with author, June 8, 2015.

64. Butch Lazorchak and Cheryl Lederle, "The K-12 Web Archiving Program: Preserving the Web from a Youthful Point of View," The Signal: Digital Preservation (blog), May 21, 2015, accessed May 30, 2015, blogs.loc.gov/digitalpreservation/2015/05/the-k-12-web-archiving-program-preservingthe-web-from-a-youthful-point-of-view.

65. Lederle, June 8, 2015.

66. Jefferson Bailey (director, Web Archiving Programs, Internet Archive), e-mails with author, November 28, 2015; Neme Alperstein (teacher, P.S. 174 William Sidney Mount), e-mails with author, November 21, 2015.

67. Ibid.

68. Alperstein, discussion with author, June 2, 2015.

69. Patricia Carlton (media specialist, Mount Dora High School), discussion with author, June 16, 2015.

70. Lederle, June 8, 2015.

71. "English Language Arts Standards: Writing," Common Core State Standards Initiative, 2015, accessed June 15, 2015, www.corestandards.org/ELA-Literacy/W/introduction.

72. Carlton, June 16, 2015.

73. Library of Congress, "America's Young Archivists: The K-12 Web Archiving Program," video, 7:59, March 7, 2011, accessed June 30, 2015, https://www.youtube.com/watch?v=Gob7cjzoX3Y\&w=42 $0 \& \mathrm{~h}=315$.

74. "Explore All Archives," Archive-It, accessed June 30, 2015, https://archive-it.org/explore?fc =organizationType\%3Ak12ProjectSchools\&show=Sites.

75. Andrew Flinn, Mary Stevens, and Elizabeth Shepherd, "Whose Memories, Whose Archives? Independent Community Archives, Autonomy, and the Mainstream," Archival Science 9, nos. 1-2 (2009): 73.

76. Lederle, June 8, 2015.

77. Work is forthcoming that will provide additional curriculum guidance for educators involved in the Archive-It K-12 Web Archiving Program.

78. Carlton, June 16, 2015.

79. Ibid.

80. Paul Bogush (teacher, James H. Moran Middle School), discussion with author, July 20, 2015.

81. Ibid.

82. Ibid.

83. "Library Staff Visits Middle School Web Archivists," Library of Congress Digital Preservation News and Events Archive, June 15, 2010, accessed June 30, 2015, www.digitalpreservation.gov/ news/2010/20100610news_article_moran.html; Bogush, July 20, 2015.

84. Bogush, July 20, 2015.

85. Alperstein, e-mails with author, June 30, 2015.

86. Ibid.

87. Common Core State Standards Initiative, 2015, accessed July 1, 2015, www.corestandards.org.

88. Carlton, e-mails with author, July 28, 2015.

89. Carlton, June 16, 2015.

90. Carlton, July 28, 2015.

91. "Welcome to Archive-It," Archive-It, captured July 1, 2008, accessed July 15, 2015, https://web .archive.org/web/20080701143220/http://www.archive-it.org/k12. 
92. “K-12 Web Archiving: About the Program," Archive-It, accessed April 23, 2016, https://archive-it .org/blog/k12-web-archiving-program/.

93. Alperstein, e-mails with author, July 10, 2015.

94. Bogush, July 20, 2015.

95. Eamon, "A 'Genuine Relationship with the Actual," 310.

96. Library of Congress, "K-12 Web Archiving: Preserving the Present," video, 4:55, from an interview with Paul Bogush on February 28, 2011, accessed July 20, 2015, www.digitalpreservation.gov/ multimedia/videos/k12preservingpresent.html.

97. Ibid.

98. Library of Congress, "America's Young Archivists."

99. Carlton, June 16, 2015.

100. Jeanette A. Bastian, "The Records of Memory, the Archives of Identity: Celebrations, Texts, and Archival Sensibilities," Archival Science 13, nos. 2-3 (2013): 122.

101. Ibid., 123.

102. Christopher A. Lee, "Collecting the Externalized Me: Appraisal of Materials in the Socialized Web," in I, Digital, ed. Christopher A. Lee (Chicago: Society of American Archivists, 2011), 203.

103. "Explore All Archives."

104. Bastian, "The Records of Memory, the Archives of Identity," 130.

105. Joan M. Schwartz and Terry Cook, "Archives, Records, and Power: The Making of Modern Memory," Archival Science 2, nos. 1-2 (2002): 2.

106. Rodney Carter, "Of Things Said and Unsaid: Power, Archival Silences, and Power in Silence," Archivaria 61 (2006): 221, accessed July 5, 2015, journals.sfu.ca/archivar/index.php/archivaria/ article/view/12541/13687.

107. Sue McKemmish, "Evidence of Me," The Australian Library Journal 45, no. 3 (1996): 176, accessed July 5, 2015, www.tandfonline.com/doi/pdf/10.1080/00049670.1996.10755757.

108. Ibid., 175, 176 .

109. Library of Congress, "America's Young Archivists."

110. Ibid.

111. Barbara Craig, Archival Appraisal: Theory and Practice (Munich: K.G. Saur, 2004), 7, 9.

112. Cook, "Evidence, Memory, Identity, and Community," 96.

113. Library of Congress, "K-12 Web Archiving: Preserving the Present."

114. Terry Cook, "Remembering the Future: Appraisal of Records and the Role of Archives in Constructing Social Memory," in Archives, Documentation, and Institutions of Social Memory: Essays from the Sawyer Seminar, ed. Francis X. Blouin Jr. and William G. Rosenberg (Ann Arbor: University of Michigan Press, 2006), 169. 